\title{
Is The Ethiopian Birr Overvalued? A Sober Assessment
}

\author{
Haile Kebret* ${ }^{1}$ and Edris Hussien*
}

\begin{abstract}
The objective of this paper is to assess whether the Ethiopian Birr is overvalued? If so, to what extent? And what are the policy options, if any, that should be followed under such circumstances? To do this an annual data from 1984 to 2013 is gathered and an Autoregressive Distributed Lag (ARDL) model is estimated in the context of bounds testing. Appropriate data diagnostics pre-and-post estimation tests are conducted to ensure result robustness, validation and tracking performance of results. The estimated model shows that the Ethiopian Birr is slightly overvalued as indicated by the spread between the nominal and the parallel exchange rates but importantly between the actual and the estimated (equilibrium) real exchange rates. The magnitude of the overvaluation is marginal (except the year when the domestic inflation was at its peak).

The most sober policy conclusion the authors reached is that devaluing the currency at the moment seems neither necessary nor useful as it is unlikely to improve the internal and external (trade) balances of the country. This conclusion is based on the following: first, the spread between the actual and the equilibrium exchange rates is minimal; second, our calculation shows that the response of Ethiopian exports and imports to a change in exchange rate is very low or inelastic; and, third, a minor spread does not necessarily call for a devaluation to improve internal and external balance in economies like that of Ethiopia; and fourth, given the pervasive information asymmetries, the net benefit of fine-tuning the exchange rate to correct minor spread is uncertain in economies that are in transition.
\end{abstract}

Keywords: International finance, Exchange rate, appreciation, Ethiopia

http://dx.doi.org/10.4314/ejbe.v5i1.1

\footnotetext{
${ }^{1}$ Correspondent Author: hailekebret@yahoo.com, phone no.: +251-11-5153262

*Both authors work as Director of Research and Junior Research Fellow, respectively, for the Horn Economic and Social Policy Institute.
} 
Appreciation of the Ethiopian Currency

\section{Introduction}

This study is motivated by the recent IMF and World Bank initiated suggestion to devalue the Ethiopian Birr and the interest it generated at times in controversial blogs. It is important that any misalignment is corrected in time and effectively. But if the spread between the actual and the equilibrium real exchange rate is insignificant, a floating peg should be able to correct it. It is, therefore, important to assess the extent of such misalignment, if any, before it either generates unnecessary anxiety or an actual distortion that affects potential and actual actors in the economy. In that regard, this study attempts to employ recent approach to assess whether the Birr is really overvalued, the degree of the misalignment, if any, and if so what policy action to take to correct the misalignment thereby to improve and maintain internal and external balance of the macro-economy.

IMF's released statement (IMF, October 2014) stated that the "Directors encouraged the authorities to improve export competitiveness by reducing overvaluation of the real effective exchange rate through enhanced exchange rate flexibility. A more market-based exchange rate would also facilitate the accumulation of foreign exchange reserves, as a buffer against external shocks." This suggestion is consistent with basic exchange rate principles. It is, therefore, imperative that countries assess whether the behavior of the attendant exchange rate is consistent with macroeconomic fundamentals. The pertinent question is, is the spread too large to be corrected in the context of a floating peg? And is the elasticity of trade large enough to warrant devaluation for a minor misalignment so that all the goals noted could be achieved? The objective of this paper is to address these questions.

The exchange rate is simply the price of a given currency in terms of another currency. A national currency is therefore simply the price of what a country 
exports relative to the price of what it imports. Or to put it differently, it is the price of tradables as a ratio of non-tradables. As such, it affects both the supply of and the demand for both goods and services domestically produced and internationally traded. Therefore, its overvaluation (above its competitive value) hurts exports and encourages imports while its undervaluation (below what is its competitive value) does exactly the opposite. As Maxwell (2003, P.2) noted " the overriding objective of exchange rate policy should be to avoid persistence in exchange rate misalignment, which is a common feature in most developing countries. However, in order to manage misalignments it is necessary to successfully identify what constitutes the equilibrium real exchange rate (ERER), and this continues to pose a fundamental difficulty in the modern literature on the real exchange rate".

In broad terms, the exchange rate regime is either fixed or floating. A fixed exchange rate is administratively determined and its value only varies from time to time when monetary authorities decide to either revalue or devalue its rate against external currencies. While this was dominant from WWII to the early 1970s under the Bretton Woods System (1944-68), since then very few countries (mainly least developed ones) have a fixed exchange rate system (regime).

The floating exchange rate regime, on the other hand, is essentially determined by market forces. Even the movements of pegged float (in which monetary authorities keep changing its value from time to time to minimize deviation from its true currency price) is influenced by movements of market forces. The floating exchange rate regime (either in its close to pure form or pegged) is the most widely used system at the moment. And clearly because it is market determined but with some fixed exchange rate features, the deviation between 
the actual exchange rate and what is termed an equilibrium exchange rate is, in most cases, minimal, i.e. deviation is marginal.

The exchange rate regime in Ethiopia has a long history. It was mainly fixed for decades until the early 1990s before it was devalued by a significant margin in 1994. Since then it has only been mainly operating under what is called a pegged floating exchange rate. That is, monetary authorities have been making periodic adjustments as they see it fit to keep the economy competitive. As could be seen from Fig. 1, the Ethiopian nominal exchange rate (Birr) against the USD was constant until the early 1990s. After that it started to depreciate until it approached about Birr 20 /USD in the last few months.

Figure 1: Official Exchange Rate Movement (Birr per US\$)

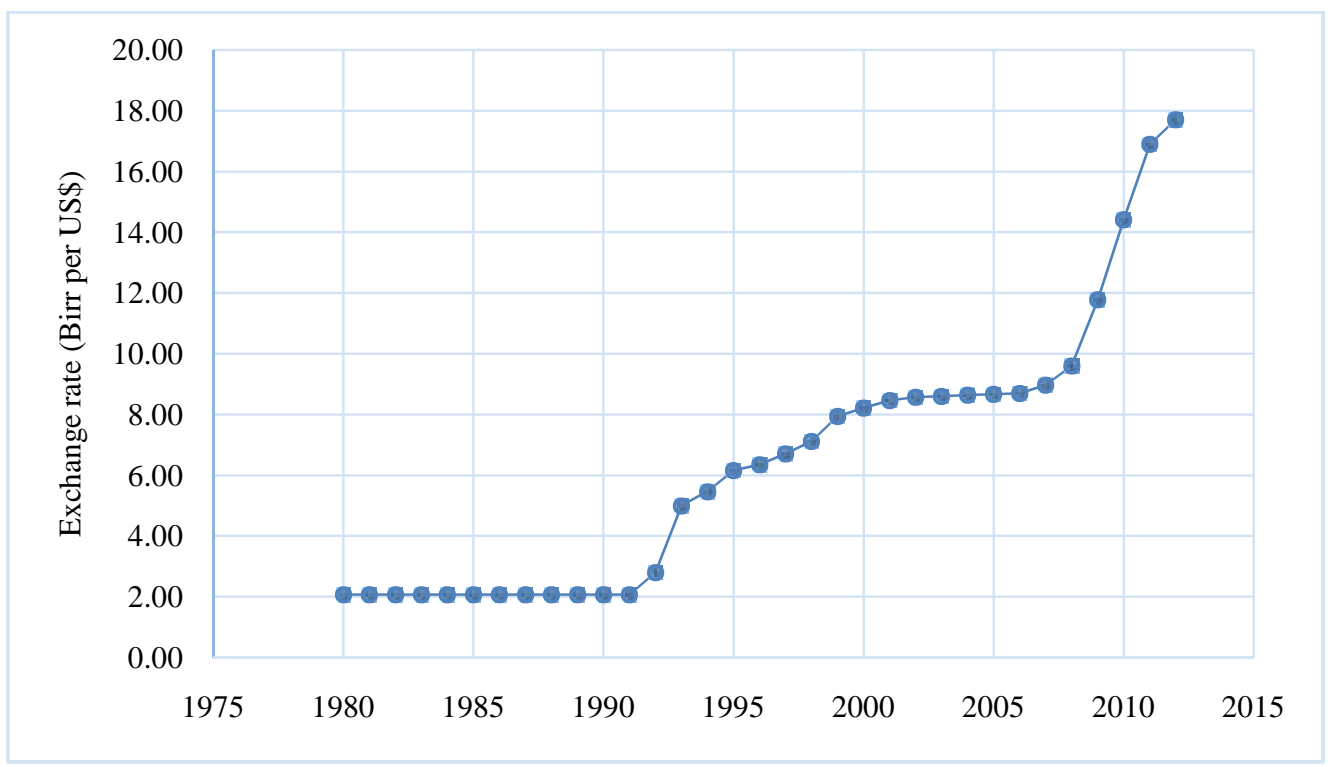

Source: World Development Indicators

The important question is, then, what are the factors that determine its movements over time? More specifically, what are the macroeconomic fundamentals that economic agents (including monetary authorities) may 
influence or monitor that could lead to an exchange rate misalignment (or deviation or spread between actual and equilibrium) exchange rates? Even though such deviations are generally minimal in a floating exchange rate system relative to a fixed exchange rate regime, misalignment could happen as the exchange rate movements lag behind the dynamic movement of economic fundamentals that influence it. This brings us to the fundamental question of what economic fundamentals influence the behaviour of the exchange rate.

The purpose of this short paper is to answer the question by examining whether the Birr is misaligned or it is close to its equilibrium value as determined by macroeconomic fundamentals. To do so, the paper estimates what is called the fundamental or equilibrium exchange rate and compares this value with the actual exchange rate to evaluate whether and /or the extent to which the actual exchange rate is consistent with the equilibrium exchange rate.

The remainder of the paper is organized as follows. Following this brief introduction, the second section briefly presents the Ethiopian economy at a glance; the third section reviews the literature which is followed by model specification, estimation and results in the fourth section. And, finally, section five concludes by examining the policy implications and suggestions based on the results obtained.

\section{The Ethiopian Economy at a Glance}

Ethiopia has recorded one of the fastest economic growth in the past decade. In 2004-2013, the Ethiopian economy grew by an average of eleven percent annually far higher than the Sub-Sahara African average of 5.3 percent. At a sectoral level, the industry sector grew by 17.1 percent followed by the service sector which grew by 10.9 percent; while the agricultural sector which 
contributes much to the overall GDP of Ethiopia grew by 4.9 percent in 2012 . Within industry, the manufacturing sub-sector grew by 11.8 percent. The contribution of the agriculture sector to the overall GDP growth has been declining as can be seen in fig. 2 below.

Figure 2: Annual Growth of GDP and Agricultural Value Added for Ethiopia (in 2000-2013)

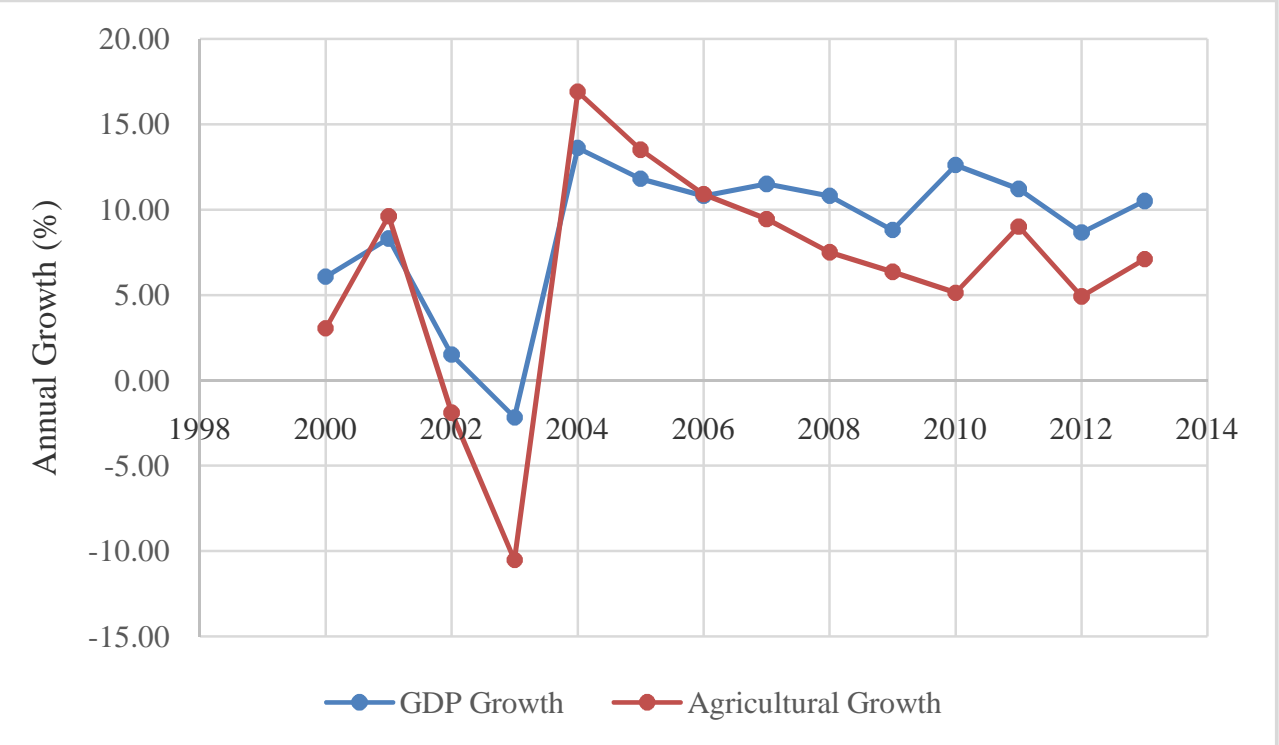

Source: World Bank (2014)

The government of Ethiopia has followed expansionary fiscal policy for the last few years; government consumption as percentage of GDP was as high as 19 percent in 2000 though declined since then and reached around 7 percent in 2012. The expansion in government expenditure could be attributed to the need to finance mega-infrastructure projects (roads, railway and dam projects) and public consumption; partly owing to this expansion, the annual inflation was high before it declined to a single digit in 2013 at 8.1 percent. 
Figure 3: Inflation, Consumer Prices (Annual Percentage Change)

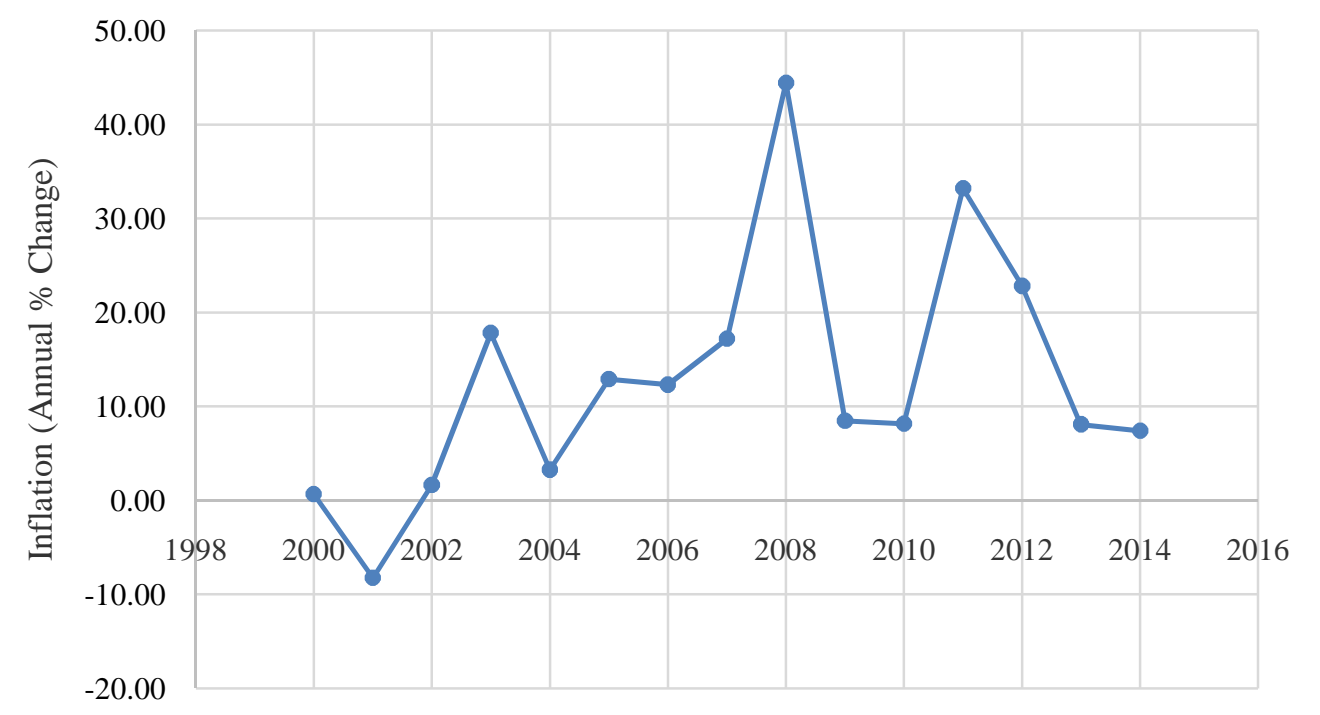

Source: World Bank (2014)

Owing to the huge expenditures on infrastructure, Ethiopia's net government balance was also mainly negative and accumulated some government debt; though improved relative to what was a decade ago (because of the HIPCs initiative), general government debt (\% of GDP) was above 100 percent of GDP in 2003/04; but since then it has been declining and reached around 17.9 percent in 2012. The IMF estimate shows that it will be 19.5 and 21.2 percent in 2013 and 2014, respectively.

Some of the main sources of development finance in Ethiopia are technical assistance or foreign aid in general, remittances and foreign direct investment. Grants excluding technical cooperation (\% of GDP) to Ethiopia hovers around 10 percent; but since 2008 it has shown decline and reached at around 5.1 percent in 2012. Net Foreign Direct investment (FDI), on the other hand, exhibited large swings from year to year (see figure 4). In 2003-04, FDI was well above 5 percent of GDP but in 2013 it constituted only 2 percent. Personal 
remittance flow, which another important source of development finance in developing countries, constituted a mere 1.1 percent of GDP in 2000-12.

Figure 4: Net FDI Inflows and Personal Remittance received (\% of GDP)

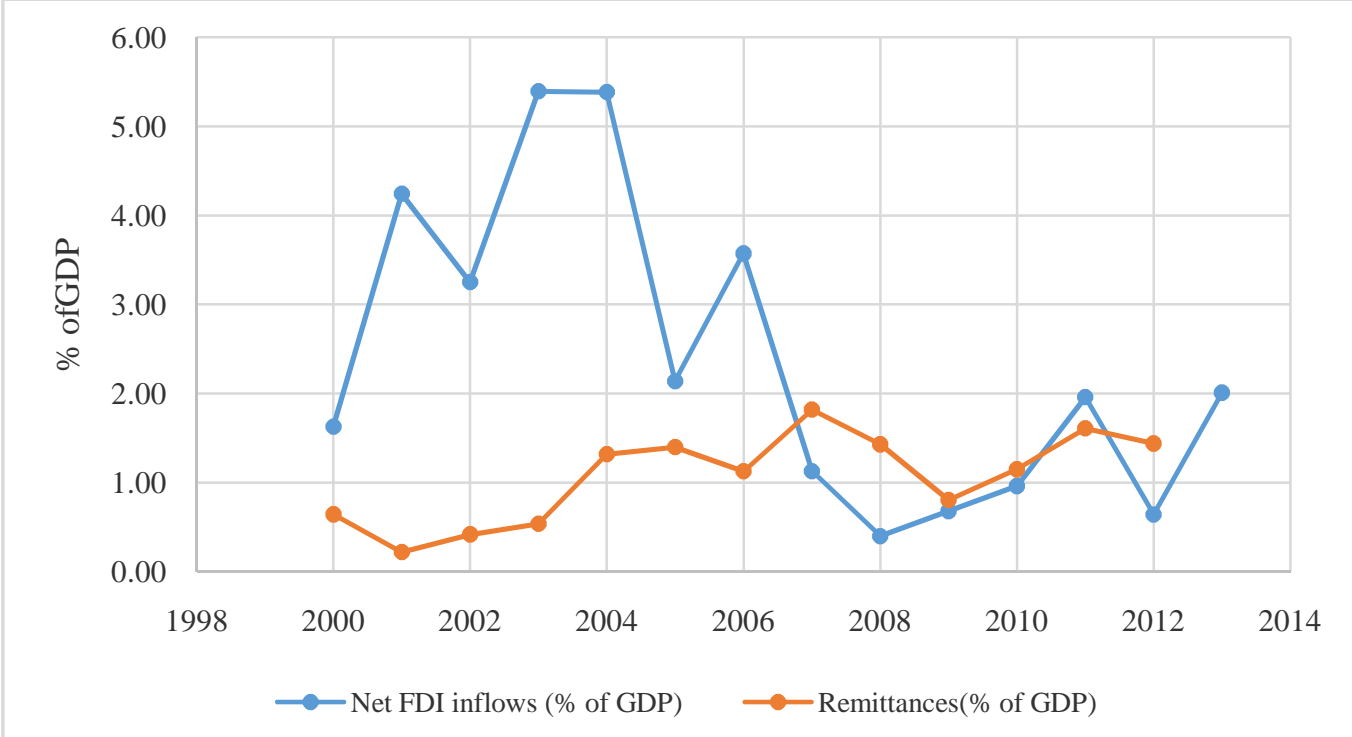

Source: World Bank (2014)

The international trade performance of the Ethiopian economy has also shown significant growth both in terms of volume and value. For instance, in the last few years, both exports and imports of goods and services have registered significant growth. Exports growth is attributed to the surge in commodity prices (especially gold and coffee) on which Ethiopia's export heavily rely on. On the other hand, the growth of imports is due to the huge demand for inputs used in production, the infrastructure activities underway and consumption goods, both public and private. But in 2012 and 2013, exports have slightly slowed down due to the decline in commodity prices in the international market and due to the slow economic growth in some trade partner countries (especially in EU). Exports as a percentage of GDP declined in 2012 by 3 percentage points from its level in 2011. The slow growth has contributed to the growing trade deficit of the country (see Fig. 5). 
Appreciation of the Ethiopian Currency

Figure 5: External Balance on Goods and Services (\% of GDP)

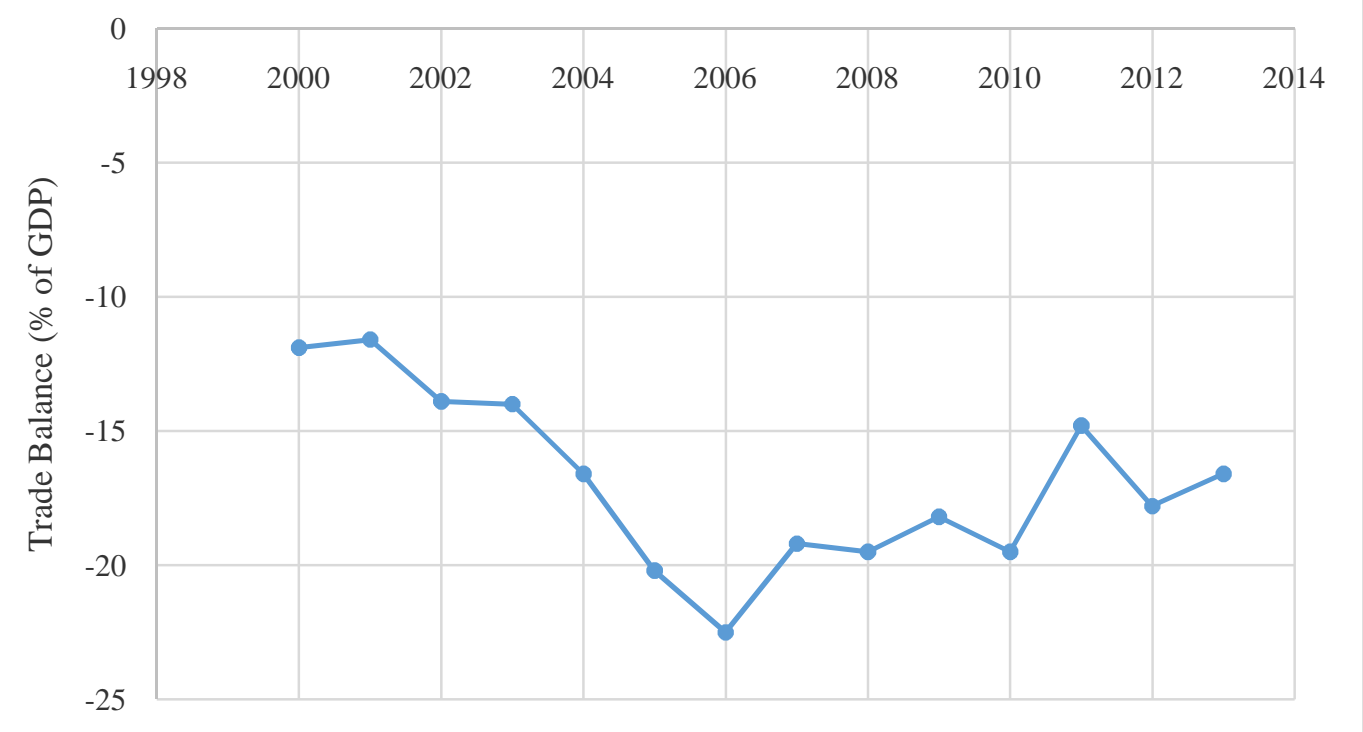

Source: World Bank (2014)

Between 2008-2012, Ethiopia's top exports markets were Germany followed by China and neighbouring Somalia and Sudan (both members of IGAD). Djibouti, another IGAD member, ranks among the top ten export destinations for Ethiopia. On the other hand, Ethiopia's import partners for the past few years include China, India and the Arab Gulf States of Saudi Arabia, Kuwait and UAE.

\section{Review of Related Literature}

The Exchange rate regime in both developing and developed countries has played a crucial role in influencing their macroeconomic policy after the collapse of the Bretton Woods System of fixed exchange rates. Since then a lot of empirical as well as theoretical works have been carried out with particular emphasis on developing countries (Edwards, 1987; 1988 \& 1989; Cottani et al, 
1990; Ghura and Grennes, 1992; Pick and Thomas, 1994; Hinkle and Montiel, 1999). Real exchange rate (RER), defined as the relative price of nontradables to tradables (or tradables to nontradables), is the most important relative price signaling the trade direction in the long-run (Elbadawi, 1994); and when there is sustained misalignment (deviation from its long-run equilibrium level), it will lead to severe macroeconomic disequilibrium (Edwards, 1988).

Edwards (1988) analysed the behaviour of RER in developing countries focusing on whether real exchange movements have historically responded to both real and nominal disturbances. The author found out that discrepancies between the actual and the equilibrium RER will tend to disappear slowly if left on their own; whereas nominal devaluations are neutral in the long run but can potentially be helpful to speed up the restoration of RER equilibrium. Consistent with the theory, long run equilibrium real exchange rate responds to economic fundamentals (Edwards, 1988, p. 89).

Following Edwards' (1989) theoretical formulation of exchange rate misalignment, Cottani et al (1990) showed the existence of strong negative correlation between economic performance indicators (per capita growth rate, export growth rate, net rate of investment, agricultural growth and incremental capital output ratio) and real exchange rate (RER) misalignment and instability in less developing countries. RER misalignment is an important factor in influencing incremental capital output ratio.

Using time series and cross sectional data for Sub-Saharan African countries, Ghura and Grennes (1993) showed that deviation of real exchange rate from its equilibrium level (misaligned exchange rate) impacts economic performance adversely. Higher level of misalignment is accompanied by higher levels of macroeconomic instability. 
Based on a well-structured but simple extension of an IS-LM model of an open economy, Razin and Collins (1997) constructed RER misalignment indicator for large sample of developing and developed countries. Then they applied regression analysis to see whether RER misalignment is related to country growth experiences. They found that there existed non-linear relationship between growth and RER misalignment indicating only high over-valuations appear to be associated with slow economic growth.

Nilsson and Nilsson (2000) analysed the effects of various exchange rate regimes on developing countries' exports by including exports of some 100 developing countries to the EU, Japan and the USA during the 1983-1992 periods. Their results indicated that the more flexible the exchange rate regime, the greater the exports of developing countries, ceteris paribus. The net effects on exports of real exchange rate misalignments (which could be over- or undervaluations) are negative, and that these effects dominate the potentially negative export effects of exchange rate volatility vis-a $a$-vis the invoicing currency of exports.

Pick and Vollrath (1994) employing the structural modelling approach to exchange rate examined the impact of exchange rate misalignment on agricultural exports supply in Developing countries. Consistent with Ghura and Grennes (1993), Pick and Vollrath (1994) showed that exchange rate misalignment, measured as the ratio of actual real exchange rate to the long run real equilibrium rate, had negative impact on agricultural export performance. In Argentina, Egypt, Cote D'Ivoire and Indonesia, the authors found that a significant adverse impact of exchange rate misalignment on commodities like maize, wheat, meat, cotton, coffee and cocoa. The impact on different commodities varies from country to country. 
To investigate the effect of exchange rate misalignment on agricultural policy measures, Cheng and Orden (2005) used data from India and China from the 1970s to 2002. They found that agricultural support levels measured by Producers Support Estimates (from 1985-2002 for India and from 1995-2001 for China) are sensitive to alternative exchange rate assumptions. Specifically, exchange rate misalignments have either amplified or counteracted the direct effects from sector-specific policies.

\section{Model Specification, Estimation and Results}

\subsection{Measures of an Exchange Rate}

Before specifying the model to be estimated, it is instructive to define a real exchange rate. The real exchange rate could be measured as the nominal exchange rate weighted by the ratio of the foreign price of tradable goods to domestic goods. That is, it simply is the nominal exchange rate scaled by world and domestic price ratios.

That is, $\quad R E R_{t}=\frac{E_{t}\left(P_{t}^{*}\right)}{P_{t}}$

Where: $R E R_{t}=$ the real exchange rate - foreign currencies per unit of domestic currency;

$E_{t}=$ the official nominal exchange rate measured as the amount of domestic currency per unit of foreign currency (US\$);

$P_{t}^{*}=$ the foreign currency price of tradables and $P_{t}$ is the domestic price of nontradables; and $\mathrm{t}$ is time subscript.

In cases where the price of tradables $\left(\mathrm{P}^{*}\right)$ is not available many researchers (Balassa -1990, Edwards -1990, 1989 and Ghura -1993, for instance), used the world or the US whole sale price index as a proxy. And the domestic price index is proxied by domestic CPI. 
It is worth noting that the way the real exchange rate is measured some times vary depending whether it is expressed in terms of foreign currency per unit of domestic currency or the other way round. This, of course, has no substantial difference except in our interpretation of upward or downward movements. In this exercise, the writers follow the National Bank of Ethiopia's definition of expressing the value of the local currency (Birr) per unit of foreign currency (in this case the USD). Therefore, an increase in the real exchange rate implies a depreciation of the Birr while a decrease indicates an appreciation. An increase in the ratio of price of tradables to the price of non-tradables will also, other things being equal, lead to a depreciation of the real exchange rate while an increase in the price of non-tradables will lead to an appreciation of the real exchange rate.

A commonly used alternative definition of the exchange rate is the real effective exchange rate (REER); this is the same as above except instead of the bilateral nominal exchange rate an index based on trading partners' currencies, is used (i.e. instead of a single currency like the EURO or Dollar, for instance). The advantage of the effective real exchange rate is it reflects the value of the exchange of the countries which are close trade partners from which the country in question imports its goods and to which it exports its goods and services (i.e. its major sources of imports and destination of its exports). This is usually a more comprehensive measure as it reflects the relevant trade transactions of the country.

Whether the above defined real exchange rates (RER or REER) are consistent with what the macroeconomic fundamentals of the country suggest or reflect the prevalence and the extent of distortion (or lack thereof) in the performance of the macro-economy. In short, both are measures of competitiveness of the economy with trading partners because it is the price by which foreign and 
domestically produced goods are scaled (or weighed). Hence, other things being equal, theory suggests a depreciation of the domestic currency (Birr in this case) to encourage what is domestically produced (or exports) and discourage what is imported from abroad. Appreciation of the currency is expected to have exactly the opposite effect (discourage exports and encourage imports).

\subsection{Model Specification}

An exchange rate that is not misaligned (not under- or overvalued) will therefore help competitiveness and ultimately a healthy current account and balance of payment positions in addition to an appropriate resource allocation in the domestic market. The main purpose of all the various studies that were conducted has, therefore, been to assess the extent to which the actual real exchange rate is consistent with the equilibrium exchange rate that would ensure such a resource allocation.

Some studies, take the year in which the purchasing power parity (PPP) is believed to approximate the equilibrium value of the exchange rate and compare any changes taking place with that year as a point of reference. But of course, this ignores the dynamic movement of the economic fundamentals that might have taken place in the economy that would seriously impact on the behaviour of the exchange rate.

Many recent studies prefer to estimate the equilibrium exchange rate using the following macroeconomic fundamentals. Chief among these include, Edwards (1990), Cottani et al (1990) and Ghura (1993), to name a few. Following Edwards (1990) and Ghura (1993), the most common specifications to estimate the real exchange rate is reported as equation (1). 


$$
\begin{gathered}
\log \left(R_{E R}\right)=\alpha_{0}+\lambda_{1} \log \left(R_{E R_{t-1}}\right)+\lambda_{2} \log \left(\operatorname{TOT}_{t-1}\right)+\lambda_{3} \log \left(\text { OPEN }_{t-1}\right)+\lambda_{4} \log \left(G C G D P_{t-1}\right)+ \\
\lambda_{5} \log \left(N O M_{-} X_{t-1}\right)+\lambda_{6}\left(\text { KAPFL }_{-1}\right)+\lambda_{7}\left(\operatorname{EXDCRE}_{t-1}\right)+\lambda_{8} D+\varepsilon_{t}
\end{gathered}
$$

Definition of the main variables and the expected signs are outlined below; $\alpha_{0}$, $\mathrm{D}$ and $\mathrm{t}$ are a constant, dummy variable and time subscript, respectively.

The terms of trade (TOT which is the price of exports relative to the price of imports) is expected to increase the availability of foreign currency as the price of exports relative to that of imports increases. This would then have both income and substitution effects and depending which one dominates it would lead to either an appreciation or a depreciation of the real exchange rate, hence a priori the sign is ambiguous. Similarly, the degree of openness (OPEN) of the economy to external trade (or closeness due to tariff and non-tariff barriers) is measured by the ratio of total exports and imports as a ratio of GDP (or GDP as a ratio of total exports and imports measure closeness of the economy).This indicates the extent to which the economy is open (or close) to the pressures of the external economy. Hence, the more open the economy is to external trade and hence exposed to external shocks, the more likely that the real exchange rate will depreciate. Some studies use the inverse of this to measure the extent to which the economy is closed.

Another important variable that is believed to affect the behaviour of the real exchange rate is the amount of capital flow (KAPFLO) to the country. This is measured as the net flow of capital from abroad to the domestic economy usually proxied by net changes in the trade balance and foreign reserves, scaled by GDP. An increase in net flows helps the country to accumulate more foreign currency and hence is expected to lead to a depreciation of the domestic real exchange rate. Similarly, the extent of excess money supply 
Appreciation of the Ethiopian Currency

growth as measured by the growth in total domestic credit less the growth in GDP (XDCRE) is also included to measure excess liquidity. Alternatively, growth rate of money (as measured by growth in broad money (BMG) is used to measure its likely impact on the domestic currency and is hence expected to lead to a depreciation of the Birr.

Government consumption as a ratio of GDP (GCGDP), is also included to capture its pressure on the exchange rate since it imports most of its goods from abroad. Hence, an increase in government consumption relative to GDP is expected to lead to a depreciation of the domestic currency (Birr). And finally, devaluation of the nominal official exchange is measured by a dummy variable (DUM) for periods when devaluation took place to capture exchange rate regime changes.

\subsection{Pre-Estimation Procedures}

In principle, equation (1) could be estimated in many ways. But in this exercise the authors used what is called an Autoregressive Distributed Lag (ARDL) model. Applying the ARDL procedure involves the following steps before the final estimation of the model is undertaken. First, a unit root test is carried out using an augmented Dickey Fuller test to ensure that the variables are stationary; it has to be noted that pre-testing is not necessary if the bounds test is to be carried out but ensuring that all the variables are integrated of order one is important; second, a co-integration test is performed using unrestricted vector autoregressive approach to ensure that (a) there indeed is a long-run relationship among the variables and (b) to determine the order of integration that indicates one unique long-run relationship among the variables; and, third, the ARDL bounds test is carried out to test if it passes the F-test criteria 
indicting that there indeed is long-run relationship among the variables that are either $\mathrm{I}(0), \mathrm{I}(1)$ or are mutually co-integrated.

The Autoregressive Distributed Lag (ARDL) Model is popularized by Pesaran, Shin and Smith (2001). This approach has three notable advantages over other competing estimation techniques. "First, unlike the Engel-granger and Johansen co-integration approaches, it can be used irrespective of whether the explanatory variables are $\mathrm{I}(0)$, I(1), or a combination of the two. Second, in Monte Carlo studies it performs better than the above two noted approaches. Third, it handles structural breaks in data series (Shahbaz, 2009, P. 92).

The short-run and long-run (combined) representation of the model is presented as equation (2).

$$
\begin{aligned}
\Delta \log (R E R)=\alpha_{0}+\sum_{i=1}^{n} \beta_{1} \Delta \log \left(R E R_{-1}\right)+\sum_{i=1}^{n} \beta_{2} \Delta \log \left(\text { OPEN }_{-1}\right)+\sum_{i=1}^{n} \beta_{3} \Delta \log \left(T O T_{t-1}\right) \\
\quad+\sum_{i=1}^{n} \beta_{4} \Delta \log \left(G C G D P_{t-1}\right)+\sum_{i=1}^{n} \beta_{5} \Delta \log \left(N O M_{-} X_{t-1}\right)+\sum_{i=1}^{n} \beta_{6} \Delta\left(K A P F L Q_{-1}\right) \\
+\beta_{7} E D C R E_{-1}+\lambda_{1} \log \left(R E R_{-1}+\lambda_{2} \log \left(\text { OPEN }_{-1}\right)+\lambda_{3} \log \left(T O T_{t}\right)\right. \\
+\lambda_{4} \log \left(G C G D P_{-1}\right)+\lambda_{5} \log \left(N O M_{-} X_{t-1}\right)+\lambda_{6}\left(\text { KAPFL }_{-1}\right)+\lambda_{7}\left(E X D C R E_{-1}\right)+\varepsilon_{t} .
\end{aligned}
$$

Before proceeding with the estimation of the long-run relationships and the short-run effects, the first step is to examine the properties of the data for stationarity (or lack thereof); this is followed by establishing whether there is a long-run relationship among the variables identified and the real exchange rate using model (2). This is accomplished by testing the unrestricted model and testing whether $\lambda_{2}=\lambda_{3}=\lambda_{4=} \lambda_{5}=\lambda_{6}=\lambda_{7}=0$ in equation (2). The computed Fstatics is then compared with the critical values tabulated by Pesaran et al (2001) and later modified by Narayan (2005) - to account for a shorter sample size. The decision rule is if the estimated F-statistics is greater than the 
tabulated values, we can reject the null hypothesis of no long-run relationship between the variables of interest. Pesaran et al (2001) identified a case in which the estimated value falls between the lower and upper critical values. In that case the outcome is inconclusive. But if it exceeds the tabulated critical value, the authors reject the hypothesis of no long-run relationships.

In sum, the pre-estimation procedures could be summarized as follows:

(a) An annual data from 1981 to 2012 for all the above variables was collected (mainly from the World Development Indicators (WDI) except exchange rate which is collected from the National Bank of Ethiopia) and used to estimate the equilibrium exchange rate;

(b) All the data were diagnosed for their statistical properties and other attributes before estimating the model.

(c) As reported in Appendix 1, the tests for stationarity using Dicky Fuller (1981) show that all the variables of interest are I(1) suggesting that they only become stationary after first differencing. As reported, none of the variables are stationary in levels even at $10 \%$ while all the variables are stationary at $1 \%$ after differencing once;

(d) The lag length was determined using the lag order criteria in which, all the variables (except: Akaike information criterion -AIC) choose one lag length as appropriate while the AIC indicated lag 2 as the appropriate lag length; but given the limited data size and the choice of all the remaining criteria, one lag was chosen as the order of integration (see Appendix 2);

(e) Further, the variables were tested for the existence of co-integration among the variables in the context of bounds testing;

(f) A Vector Auto Regression co-integration estimation indicated that both the variables are integrated and there is one (unique) rank as indicated by Trace and Eigenvalue statistics (see Appendix 3); and 
(g) A bound testing co-integration estimation was also carried out to double check the existence of a unique co-integration; the computed F-tests exceed the critical value tabulated by Pesaran et al (2001) and Narayan (2005). On the basis of the F-statistics (not reported), the researchers cannot reject the hypothesis of "no co-integration" of these variables; it should be noted that this is less of concern since all the variables are I(1) and there was only one co-integration among the variables (appendix 3);

\subsection{Estimation and Results}

In estimating an ARDL model, as Baek and Koo (2009, p.6) noted, 'the robust results for the ARDL model typically rely on two assumptions: exogeneity of explanatory variables and the existence of a unique long-run relationship among the variables. This is ensured if the explanatory variables are exogenous and there is a co-integration among the variables. This is, important because in the absence of these two conditions the researchers cannot guarantee the existence of a unique equilibrium relationship between the variables of interest. All these tests were carried out in this study as reported in the Appendix.

As noted above, the central question of this study examines whether the Ethiopian Birr is overvalued or not and if so how seriously. The long-run and the short-run equations are estimated using annul data (1981-2012). Some of the data was rechecked and compared with World Development Indicators (2013). Further, because some devaluation episodes were observed during the sample period, a dummy variable was included for the relevant periods, to see if it captures any regime shift but it was dropped because it was statistically insignificant in both the short-run and the long-run. Both the specification of the models, the variables included and the estimation method are consistent 
with the existing literature (see Edwards, 1990; Cottani.et al 1990; and Ghura 1993, for instance).

A brief description of the estimation results for both the long-run and the shortrun models are presented below. The variables used in estimating the long-run and error correction model are the same. Further, in the context of cointegration, a Fully Modified OLS (FMOLS) was used in estimating both models, since the results were the most robust relative to, say, Dynamic OLS (DOLS) or the Cannonical Co-integration Regression (CCR). In broad terms, the short-run model is simply the error correction version of the long-run model. As could be seen from the respective tables, the results of the estimated long-run and short-run equations indicate that most of the variables of interest are statistically significant and with signs as theoretically predicted. Further, as will be discussed in the validation process, the statistical attributes are acceptable suggesting the fit, on the whole, is acceptable.

In both the short-run and the long-run, openness of the economy to the external world exhibited a perverse sign; this might be due to the following two domestic economic circumstances: First, the Ethiopian economy has only been relatively more open in recent years; and, second, the external sector has always been disproportionately dominated by imports relative to exports which leads to scarcity of foreign exchange and hence likely more to lead to the appreciation of the local currency and, hence, a negative sign. While the basic theoretical insight in the literature reasons that the more open the domestic economy is to the rest of the world the more the pressure on the local exchange rate to depreciate. But the Ethiopian economy might be affected by the attendant export and import structures to the contrary, despite the usual theoretical prediction. The government consumption to the ratio of GDP (GCGDP) has the expected positive sign in the short-run but why it is negative 
in the long-run is difficult to explain, unless it has to do with the patterns of government consumption. However, since our immediate concern in this exercise is the short-run behaviour of the exchange rate, its long-run sign is of less concern. And the measure of a dummy variable that is supposed to account for the period when there was a break was not statistically significant in both the long-run and the short-run.

Table (1): Within Sample Forecast of the Short-Run Model

Dependent Variable: (Log(RER))

Method: Fully Modified Least Squares (FMOLS)

Included observations: 28 after adjustments

Cointegrating equation deterministic: $\mathrm{C}$

Long-run covariance estimate (Bartlett kernel, Newey-West fixed bandwidth $=4.0000$ )

\begin{tabular}{ccccc}
\hline \hline Variable & Coefficient & Std. Error & t-Statistic & Prob. \\
\hline \hline$(\log ($ RER $(-1)))$ & 0.142937 & 0.124213 & 1.150736 & 0.2649 \\
$(\log ($ OPEN $(-1)))$ & -0.542654 & 0.083049 & -6.534115 & 0.0000 \\
$(\log ($ TOT $(-1)))$ & -0.592992 & 0.162796 & -3.642539 & 0.0019 \\
$(\log ($ GCGDP $(1)))$ & 0.298715 & 0.072499 & 4.120256 & 0.0006 \\
$(\log ($ NOM_X $(1)))$ & 0.998069 & 0.123675 & 8.070105 & 0.0000 \\
$($ KAPFLO(1)) & 0.395143 & 0.322920 & 1.223653 & 0.2369 \\
$($ EXDCRE $(1))$ & 0.000881 & 0.000343 & 2.570220 & 0.0193 \\
ECM_EXC(-1) & -0.969105 & 0.157408 & -6.156657 & 0.0000 \\
C & -0.032376 & 0.017311 & -1.870314 & 0.0778 \\
& & & & \\
\hline \hline R-squared & 0.806864 & Mean dependent var & 0.017566 \\
Adjusted R-squared & 0.710296 & S.D. dependent var & 0.154293 \\
S.E. of regression & 0.083047 & Sum squared resid & 0.124142 \\
Long-run variance & 0.002383 & & & \\
\hline \hline
\end{tabular}

As noted above, the short-run (and the long-run in Appendix 5) exhibit acceptable attributes judged in terms of overall signs, explanatory power (even the coefficient of variation in the short-run is relatively high), the residual sum 
of squares, standard error of regression and long-run variance. Further, more formal and appropriate diagnostic tests were carried out so that the results are not affected by detectable biases. For instance (as noted in Appendix 4), formal tests for serial correlation using LM test, Ramsey Reset test for correct model specification, $\mathrm{ARCH}$ and White tests for Heteroskedasticity and test for normality using Jarque Bera (not reported to save space) were conducted. In all the cases, no detectable problems were found and the respective null hypotheses cannot be rejected using appropriate tests.

It is also worth highlighting that the error correction term is statistically significant, and has the right sign and the magnitude of the coefficient suggests that about $96 \%$ of any deviation is corrected within the period. Admittedly, the speed of adjustment seems to be on the high side since it suggests that any deviation from equilibrium is corrected in a very short period; but this is to be expected in a crawling-peg exchange rate regime which has both the attributes of a fixed exchange rate and a floating exchange rate regime in which the spread is expected to be minimized in a short span of time.

More importantly, the validation process also indicates that the model predicts well the historical movements of the exchange rate. The within sample and one year outside sample validation process show that the forecasts (representing the equilibrium exchange rate) mimic the actual exchange rate values, particularly in the short-run as shown in Fig. 6 (even in the long-run Appendix 5).That is, the spread between the actual and estimated (equilibrium) real exchange rates is minimal (as represented by the good fit or small residuals). It also predicts the turning points very well and the residual sum of squares (not reported) is very small. All these attributes suggest the model is well specified.

Fig. 6: Within Sample Forecast of the Short-Run Model 


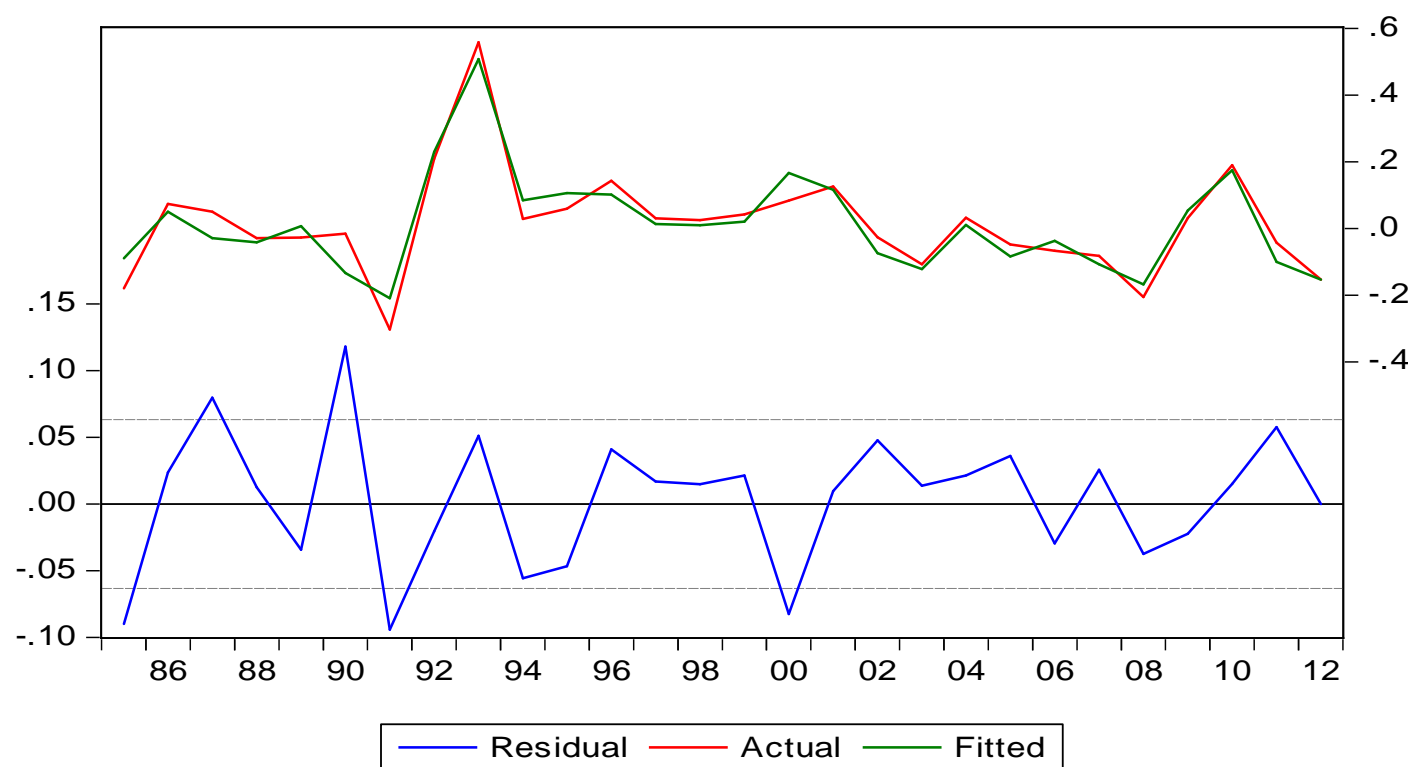

Source: Own computation based on the regression result

\section{Brief Summary and Policy Suggestions}

\subsection{Summary and Policy Implications}

The objective of the study has been to explore whether the Ethiopian Birr is overvalued or not and if so to assess the extent of the misalignment of the local currency (Birr). In doing so it has used a relatively recent and appropriate estimation technique given the limitation of data for some of the variables of interest and the current state and availability of the Ethiopian data (i.e. its consistency and continuity).

Despite data limitations and possible weaknesses of the existing data, the study attempted to apply what the authors believed is a relatively recent and appropriate technique to address the issue. Without going into details, the procedure and the results of the exercise could be summarized as follows: 
$\checkmark$ Most of the variables of interest have the theoretically expected signs in both the long-run and short-run,

$\checkmark$ In addition to the theoretically expected signs, the within sample shortrun dynamic simulation forecasts (shown in Fig. 6 and the long-run forecasts (appendix 6) mimic very well even the turning points which suggest that the model is well specified to account for the movements of the real exchange rate during the period of estimation;

$\checkmark$ Further, as the diagnostic test (Appendix 4) shows, the results pass the tests for serial correlation, Ramsey Reset test for correct model specification, ARCH and White tests for Heteroskedasticity and normality; $\checkmark$ As an additional test for the forecasting ability of the model, in addition to the within sample forecasts for which actual data is available, additional forecasts for the last year were taken and compared with relevant variables of interest;

$\checkmark$ In that context, the actual real exchange rate and the equilibrium (estimated) exchange rate, the nominal (official) and the parallel exchange rate are compared. Fig. 7 shows that the Ethiopian Birr is slightly overvalued. In particular, this is reflected in the spread between the actual and the equilibrium (estimated) real exchange rates;

$\checkmark$ In terms of magnitude, the overvaluation is marginal; the main deriver (culprit) for the slight overvaluation in recent years seems to be the high domestic price relative to international price level. Periodic analyses of the deviation are also consistent with the high inflation episodes in the national economy relative to international levels of inflation. 
Fig. 7: Movements in Exchange Measures

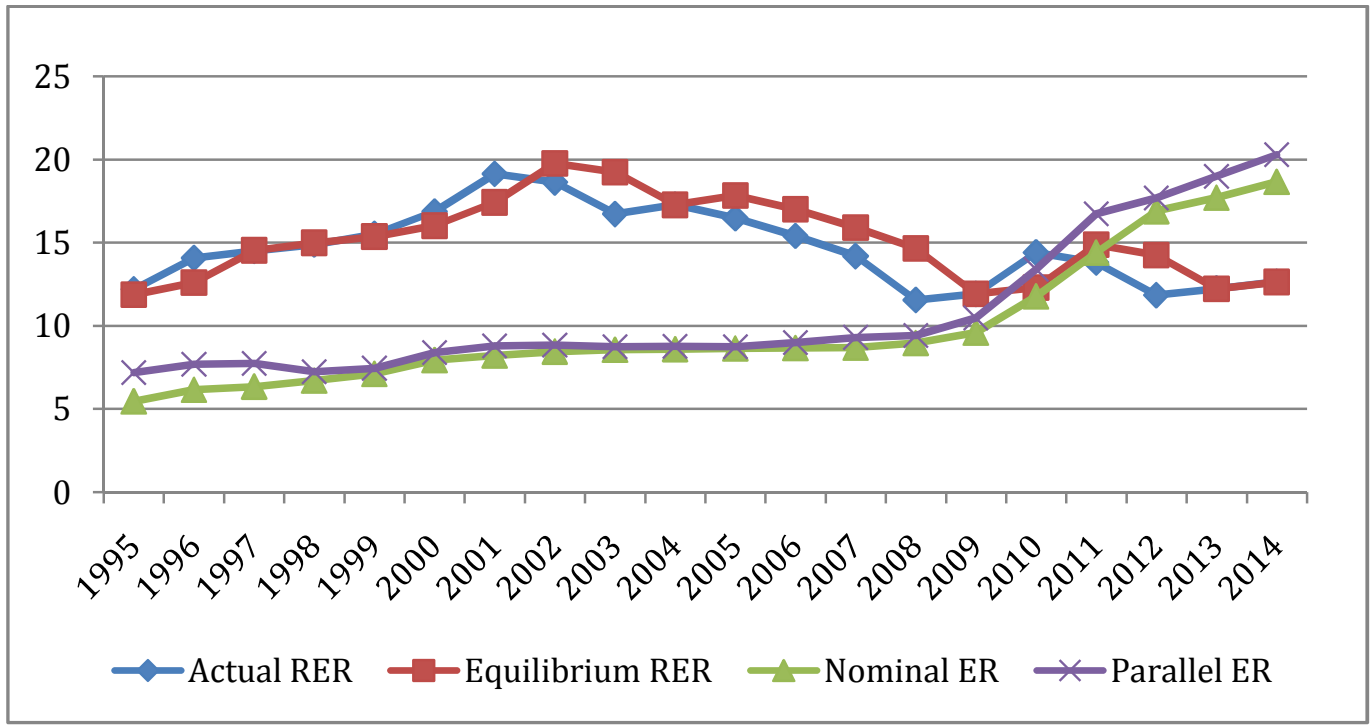

Source: Own computation based on the regression result

The next important question to ask is what is the appropriate policy action to optimize the performance of an economy like that of Ethiopia when such a misalignment is observed? In particular when:

a. The magnitude of the misalignment minor that could possibly be corrected with a floating peg as the government has been doing for some time;

b. The elasticity of imports and exports is very small or what is called elasticity pessimism seems likely to hold;

c. More importantly, the role of expectations in price and exchange rate formation is extremely high; and

d. The net benefit to the economy by devaluing the currency to correct the misalignment and the disruptions to the economy that it brings (because of the above factors) cannot be ascertained; under these conditions, is the policy option obvious? 
In the absence of addressing some or all of the above issues, it is difficult to reach a conclusion regarding the appropriate policy to follow every time the spread between the actual and the parallel exchange rate shows divergence.

\subsection{Policy Implications and Conclusions}

In an effort to suggest what policy to follow, if any, the study attempted to answer some of the above raised issues.

First, it attempted to explore the degree of misalignment of the Ethiopian Birr in the last three years by comparing the deviation of the actual real exchange rate from the equilibrium or fundamental exchange rate. As could be seen from Fig. 7, the deviation is marginal. Though the spread between the nominal and the parallel exchange rates is slightly bigger, the spread between the real (actual and equilibrium) exchange rates is not very big; the increase in inflation in previous years and its recent decline to a single digit probably contributed to this outcome.

Second, the study calculated the import and export elasticities to assess the extent to which exports will increase and imports will decrease if the Ethiopian Birr is devalued. The numbers the authors arrived at are very small (an average of 0.03 for exports and 0.21 for imports). That is, to put in the profession's jargon, Ethiopian exports and imports are very price inelastic (i.e. don't change much because of a change in their prices). The rationale why this is the case could be easily explained intuitively. Ethiopia mainly exports raw agricultural commodities and imports basic manufacturing and consumption goods. Both categories of imports are essential for production and consumption, respectively, and neither changes much because of prices nor have many immediate substitutes. Both exports and imports, therefore, have low responses (or elasticities) to change in prices. Note that the overarching objective of 
devaluing a currency is to improve the balance of payments by encouraging exports and discouraging imports, If both do not respond effectively, devaluation would worsen (not improve) the balance of payments, at least in the short-run, because of what is called the J-curve effect.

Third, in economies like that of Ethiopia, partly due to pervasive information asymmetries, the role of expectations in price and exchange rate formation is mainly influenced by herding mentality and unfounded rumours. The more frequently the government officially devalues the currency the more people expect to do the same every time someone suggests to that effect. This breads instability and erodes public credibility. Establishing some semblance of normality, consistency and continuity and periodically making adjustment as the National Bank of Ethiopia has been doing on a daily and weekly basis is less destabilizing and effective in making minor adjustments to correct the relatively minor spread between the actual and the equilibrium exchange rates, as it seems the case at hand;

Fourth, it is difficult to quantify the net benefit to the economy by devaluing the currency to reduce or eliminate the spread or the disruptions to the economy that devaluation may introduce in the economy in the context of a counter factual analysis. This is because the authors could neither know what could have happened if devalued nor foretell what the future holds if the National Bank doesn't devalue.

The most sober conclusion that could be reached is that the Ethiopian Birr seems to be marginally overvalued, but because of the above outlined factors, devaluing the currency at the moment seems neither necessary nor useful as it is unlikely to improve the external (trade) position of the country. The policy implications of the conclusion must be emphasised again. It should be clear that for an import dependent economy and with price inelastic exports and 
import structure, currency devaluation every time a 'spread is observed' does not necessarily improve a trade balance or help eliminate distortions in the working of the macro-economy. 
Appreciation of the Ethiopian Currency

\section{References}

Balassa, B. 1964. The Purchasing Power Doctrine: A Reappraisal. Journal of Political Economy. pp. 584-596.

Black, Stanley S. 1972. The Use of Rational Expectations in Models of Speculation. The Review of Economics and Statistics. Vol. 54, No.

2. pp. 161-165.Britton.

AJ. C. Britton. 1970. The Dynamic Stability of the Foreign-Exchange Market. The Economic Journal. Vol. 80, pp. 91-96.

Dicky, D. A. and A. Fuller. 1981. Likelihood Ratio Statistics for Autoregressive Time Series with a Unit Root. Econometrica. Vol. 49, pp. 1057-1072.

Dornbusch, R. 1976. Expectations and Exchange Rate Dynamics. The Journal of Political Economy. Vol. 84, pp. 1161-1176.

Cheng, F. and D. Orden. 2005. Exchange Rate Misalignment and Its Effect on Agricultural Producer Support Estimate: Empirical Evidence from India and China. IFPRI MTID Discussion Paper, No. 81.

Cottani, J. A., Cavallo, D. F. and Khan, M. S. 1990. Real Exchange Rate Behaviour and Economic Performance in LDCs. Economic Development and Cultural Change. Vol. 39 No. 1, pp.61-76.

Edwards, Sebastian. 1987. Exchange Rate Misalignment in Developing countries. NBER Discussion Paper. No. 442.

Edwards, Sebastian. 1988. Real and Monetary Determinants of Real Exchange Behaviour: Theory and Evidence from Developing Countries. Journal of Development Economics. Vol. 29, pp. 311-341.

Edwards, Sebastian. 1989. Real exchange rates in developing countries: concepts and measurement. NBER Working Paper, No. 1950.

Edwards, Sebastian. 1989b. Tariffs, Capital Controls and Equilibrium Real 
Appreciation of the Ethiopian Currency

Exchange Rates. The Canadian Journal of Economics. Vol. 22

No. 1, pp. 79-92.

Edwards, Sebastian. 1989. Real Exchange Rates Devaluation and Adjustment, The MIT Press, Cambridge, MA.

Elbadawi, I. 1994. Estimating Long-Run Equilibrium Real Exchange Rates. In John Williamson, (ed) Estimating Equilibrium Exchange Rates.

Washington, D.C.: Institute for International Economics.

Ghura, D. and Grennes, T. J. 1993. The Real Exchange Rate and Macroeconomic Performance in Sub-Saharan Africa. Journal of Development Economics. No. 42, pp. 155-174.

Haile Kebret Taye. 2011. Is the Botswana Pula Misaligned? Botswana Institute for Development Policy Analysis Working Paper No. 33, March, 2013.

Haile Kebret Taye.1994. Was the Ethiopian Currency (Birr) Overvalued? In M. Tadesse, and A. B. Kello, eds. The Ethiopian Economy: Problems of Adjustment, Addis Ababa.

Haile, Kebret Taye. 1999. The Impact of Devaluation on Macroeconomic Performance: The Case of Ethiopia. Journal of Policy Modelling. Vol. 2, No. 5, pp. 481-496.

Hinkle, L. E. and Montiel, P. J. 1999. Exchange Rate Misalignment: Concepts and Measurements for Developing Countries. Oxford University Press.

International Monetary Fund. 2014. Consultations and Country Review, June 2014 and Press Release October 2014.

MacDondald, R. 1995. Long-Run Exchange Rate Modelling: A Survey of the Recent Evidence. IMF Staff Papers. 42, PP. 437-489.

MacDonald, R., and L. Ricci. 2003. Estimation of the Equilibrium Real Effective Exchange Rate for South Africa. IMF Working Paper 
Appreciation of the Ethiopian Currency

WP/03/44.

Magee, Stephen P. 1975. Prices, Incomes, and Foreign Trade. In: Peter B.

Kenen. (Eds.), International Trade and Finance: Frontiers for

Research. Cambridge. PP. 175-252.

Maxwell O., Morrisey, O. and Lloyd, T. 2003. Real Exchange Rate Response to Aid Inflows: A Dynamic Analysis for Ghana. Credit Research Paper, No. 04/12.

Muth, John F. 1961. Rational Expectations and the Theory of Price Movements. Econometrica. Vol. 29, pp. 315-335.

Naraya, P.K. 2005. The Saving and Investment Nexus for China: Evidence from Co-integration Tests. Applied Economics. Vol. 37, pp. 1979 $-1990$.

National Bank of Ethiopia (NBE), Quarterly Data (Various years).

Nilsson, K. and Nilsson, L. 2000. Exchange Rate Regimes and Export Performance of Developing Countries. The World Economy. Vol. 23 No. 3, pp. 331-349.

Niehans, Jürg. 1975. Some Doubts about the Efficacy of Monetary Policy under Flexible Exchange Rates. Journal of International Economics. Vol. 5, pp. 275-281.

Orcutt, Guy H. 1950. Measurement of Price Elasticities in International Trade. The Review of Economics and Statistics. Vol. 32, pp. 117-132.

Pick, D. H. and Vollarth, T. L 1994. Real Exchange Rate Misalignment and Agricultural Export Performance in Developing Countries. Economic Development and Cultural Change. Vol. 42 No. 3. PP. 555-571.

Pesaran, H.andYongcheol Shin.1997. An Autoregressive Distributed Lag Modeling Approach to Co-integration Analysis. Trinity College, Department of Economics, Cambridge England, January. 
Pesaran, M. Hashem and Yongcheol Shin, and R. J. Smith. 2001. Bounds Testing Approaches to the Analysis of Level Relationships. Journal of Applied Economics. Vol. 16, pp. 289-326.

Razin, O. and Susan M. Collins, S. M. 1997. Real Exchange Rate Misalignments and Growth. NBER Working 6174.

Sohmen, Egon. 1969. Flexible Exchange Rates. Rev. Ed., Chicago, University of Chicago Press.

Stock, J. and Watson. M. 1993. A Simple Estimator of Co-integrating Vectors in Higher Order Integrated System. Econometrica. Vol. 5, pp. 1035-1056.

Williamson, John.1973. Another Case of Profitable Destabilising Speculation. Journal of International Economics. Vol. 3, pp. 77-83. World Bank. 2014. World Development Indicators. 
Appreciation of the Ethiopian Currency

\section{Appendices}

Appendix 1: Stationarity and expected signs of the specified variables

\begin{tabular}{|c|c|c|c|}
\hline $\begin{array}{l}\text { Variable } \\
\text { Names }\end{array}$ & Definition & $\begin{array}{c}\text { Order of } \\
\text { Integration }\end{array}$ & $\begin{array}{l}\text { Expected } \\
\text { signs }\end{array}$ \\
\hline $\log (\operatorname{RER}(-1))$ & Real exchange Rate & $\mathrm{I}(1)$ & \\
\hline $\log (\mathrm{OPEN}(-1))$ & $\begin{array}{l}\text { Trade Openness ( } \% \text { of } \\
\text { GDP) }\end{array}$ & $\mathrm{I}(1)$ & $(+)$ \\
\hline $\log (\mathrm{TOT}(-1))$ & Terms of trade & $\mathrm{I}(1)$ & \pm \\
\hline $\log (G C G D P(-1))$ & $\begin{array}{l}\text { Government expenditure } \\
(\% \text { of GDP })\end{array}$ & $\mathrm{I}(1)$ & + \\
\hline Log(NOM_X(-1)) & Nominal exchange rate & $\mathrm{I}(1)$ & + \\
\hline KAPFLO(1) & $\begin{array}{l}\text { Capital flow measured by } \\
\text { Net changes in trade } \\
\text { balance }\end{array}$ & $\mathrm{I}(1)$ & + \\
\hline EXDCRE(1) & $\begin{array}{l}\text { Excess credit measured as } \\
\text { growth of money supply } \\
\text { less growth of GDP }\end{array}$ & $\mathrm{I}(1)$ & + \\
\hline$\frac{1}{\infty}$ & $\begin{array}{l}\text { Respective constants and } \mathrm{t} \\
\text { is time subscript }\end{array}$ & --- & \\
\hline
\end{tabular}

Appendix 2: VAR Lag Order Selection Criteria (Sample: 1981-2013)

\begin{tabular}{|l|l|l|l|l|l|l|}
\hline Lag & LogL & LR & FPE & AIC & SC & HQ \\
\hline 0 & 43.0611 & NA & 0.000471 & -2.00421 & -1.34414 & -1.79749 \\
\hline 1 & 58.2159 & $20.9032 *$ & $0.00022^{*}$ & -2.77351 & -1.92485 & $-2.5077 *$ \\
\hline 2 & 62.2417 & 4.997521 & 0.000231 & $2.77529 *$ & -1.73803 & -2.45043 \\
\hline
\end{tabular}

*Indicates lag order selected by the criterion

LR: Sequential modified LR test statistic (each at 5\% level)

FPE: Final prediction error

AIC: Akaike information criterion

SC: Schwarz information criterion

HQ: Hannan-Quinn information criterion 
Appreciation of the Ethiopian Currency

Appendix 3: Unrestricted Co-integration Rank

\begin{tabular}{|c|c|c|c|c|c|}
\hline & $\begin{array}{l}\text { Hypothesi } \\
\text { zed No. } \\
\text { of CE(s) }\end{array}$ & $\begin{array}{l}\text { Eigenvalu } \\
\mathrm{e}\end{array}$ & $\begin{array}{l}\text { Trace } \\
\text { Statistic }\end{array}$ & $\begin{array}{l}\text { Hypothes } \\
\text { ized No. } \\
\text { of CE(s) }\end{array}$ & $\begin{array}{l}\text { Eigenval } \\
\text { ue }\end{array}$ \\
\hline Trace & None * & 0.49721 & \multirow{2}{*}{\multicolumn{2}{|c|}{$\begin{array}{l}\text { 24.11739 None } * \\
\text { 4.865058 At most } 1\end{array}$}} & 0.49721 \\
\hline Statistic & At most 1 & 0.15949 & & & 0.15949 \\
\hline Max & None $*$ & 0.49721 & 19.2523 & None * & 0.49721 \\
\hline $\begin{array}{l}\text { eigenva } \\
\text { lue }\end{array}$ & At most 1 & 0.15949 & 4.86505 & At most 1 & 0.15949 \\
\hline
\end{tabular}

* Denotes rejection of the hypothesis at the 0.05

level\&**MacKinnon-Haug-Michelis (1999) p-values

Appendix 4: Diagnostic Tests for the Short-run Model

\begin{tabular}{|l|l|l|l|l|}
\hline Diagnostic Test & $\begin{array}{l}\text { A: Test } \\
\text { Statistics }\end{array}$ & $\begin{array}{l}\text { B: Critical } \\
\text { Value }\end{array}$ & $\begin{array}{l}\text { Decision } \\
\text { Rule }\end{array}$ & Conclusion \\
\hline $\begin{array}{l}\text { LM Serial } \\
\text { Correlation } \\
\text { H0: No Serial } \\
\text { Correlation }\end{array}$ & 5.010002 & 9.69868 & $\begin{array}{l}\text { Reject } \\
\text { H0 if } \\
\text { A>B }\end{array}$ & $\begin{array}{l}\text { Cannot reject } \\
\text { the null } \\
\text { hypothesis }\end{array}$ \\
\hline $\begin{array}{l}\text { Ramsey Reset } \\
\text { Test } \\
\text { Ho: Model is } \\
\text { correctly specified }\end{array}$ & 11.67917 & 12.7300 & $\begin{array}{l}\text { Reject } \\
\text { H0 if } \\
\text { A>B }\end{array}$ & $\begin{array}{l}\text { Cannot reject } \\
\text { the null } \\
\text { hypothesis }\end{array}$ \\
\hline $\begin{array}{l}\text { ARCH } \\
\text { Heteroskedasticity } \\
\begin{array}{l}\text { Ho: } \\
\text { Homoskedasticity }\end{array}\end{array}$ & 0.428847 & 0.452548 & $\begin{array}{l}\text { Reject } \\
\text { Ho if } \\
\text { A>B }\end{array}$ & $\begin{array}{l}\text { Cannot reject } \\
\text { the null } \\
\text { hypothesis }\end{array}$ \\
\hline $\begin{array}{l}\text { White } \\
\text { Heteroskedasticity } \\
\text { Ho: } \\
\text { Homoskedasticity }\end{array}$ & 7.894084 & 30.72202 & $\begin{array}{l}\text { Reject } \\
\text { H0 if } \\
\text { A>B }\end{array}$ & $\begin{array}{l}\text { Cannot reject } \\
\text { the null } \\
\text { hypothesis }\end{array}$ \\
\hline
\end{tabular}

EJBE Vol. 5 No. 1/2015 
Appreciation of the Ethiopian Currency

Appendix 5: Long-Run Model of the Real Exchange Rate

Dependent Variable: LRER

Method: Fully Modified Least Squares (FMOLS)

Sample (adjusted): 19832012

Included observations: 30 after adjustments

Cointegrating equation deterministic: $\mathrm{C}$

Long-run covariance estimate (Bartlett kernel, Newey-West fixed

bandwidth $=4.00000$ )

\begin{tabular}{lcccc}
\hline \hline Variable & Coefficient & Std. Error & t-Statistic & Prob. \\
\hline \hline $\log ($ RER(-1)) & 0.519973 & 0.112192 & 4.634690 & 0.0001 \\
$\log ($ OPEN(-1)) & -0.225929 & 0.085209 & -2.651479 & 0.0146 \\
$\log ($ TOT(-1)) & -0.945007 & 0.167441 & -5.643829 & 0.0000 \\
$\log ($ GCGDP(-1)) & -0.127226 & 0.078106 & -1.628885 & 0.1176 \\
LOG(NOM_X(-1)) & 0.421070 & 0.090423 & 4.656691 & 0.0001 \\
KAPFLO(1) & 0.828217 & 0.382422 & 2.165716 & 0.0414 \\
EXDCRE(1) & 0.001706 & 0.000647 & 2.635386 & 0.0151 \\
C & 5.872321 & 0.858180 & 6.842760 & 0.0000 \\
\hline \hline R-squared & 0.946982 & Mean dependent var & 2.429100 \\
Adjusted R-squared & 0.930113 & S.D. dependent var & 0.376741 \\
S.E. of regression & 0.099596 & Sum squared resid & 0.218227 \\
Long-run variance & 0.004386 & & & \\
\hline \hline
\end{tabular}

EJBE Vol. 5 No. 1/2015

Page 35 
Appendix 6: With Sample Forecast of the Long-Run-Model

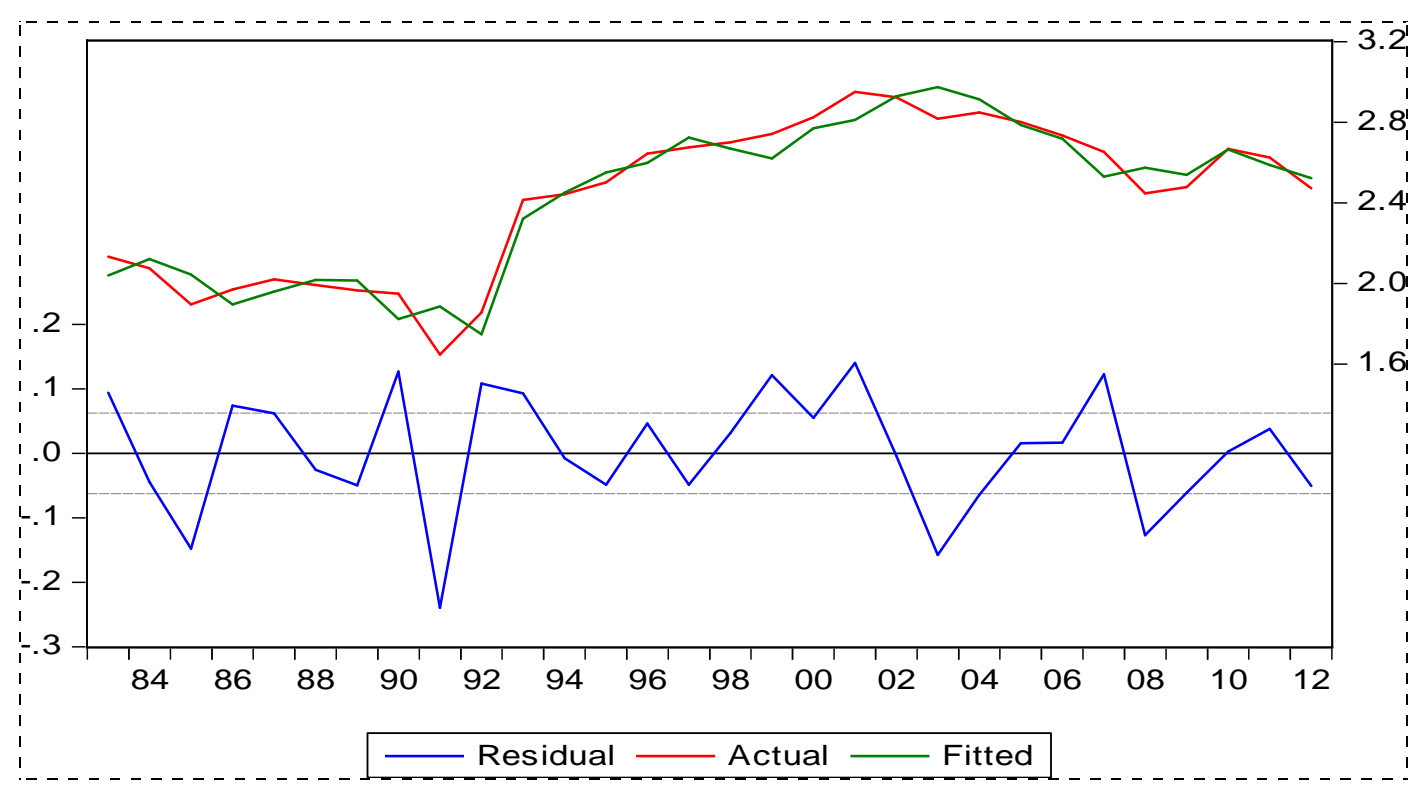

